\title{
An Assessment on Additive Manufacturing Technique to Fabricate Integral PEM Fuel Cell/Electrolyser Component
}

\author{
Arunkumar Jayakumar ${ }^{*}$ \\ *Auckland University of Technology, New Zealand-1142
}

\begin{abstract}
Additive Manufacturing (AM) is a reliable technique to build multifunctional components with any complex geometry. The present paper assesses the role of two vital AM techniques, namely Selective Laser Sintering (SLS) and Selective Laser Melting (SLM) in the fabrication of integral Polymer Electrolyte Membrane (PEM) fuel cell/electrolyser component. Thus, the paper integrates the state-of-the-art technologies, namely additive manufacturing and fuel cell/electrolyser engineering. The US department of energy (US-DoE) target can be comprehensively accomplished for the fuel cell/electrolyser stack components in a cost-effective approach. The fundamental PEM fuel cell/electrolyser components considered in the present study are the bipolar plate and gas diffusion layer (GDL).
\end{abstract}

\section{Introduction}

Additive manufacturing (AM) technique provides the feasibility to produce 3D specimen (of virtually any geometry) directly from CAD models by fusing materials, contributing the agility to construct complex parts by coalescing materials layer by layer [1] that are not possible by subtractive manufacturing processes. As a consequence, it has a prospective application in diverse engineering fields such as aerospace, automotive, biomedical and energy sector [2]. The selective laser sintering (SLS)/Selective Laser Melting (SLM) process, is a subsection of $\mathrm{AM}$ technique, and was developed in the 1980s by Carl Deckard from the University of Texas, USA. As an additive manufacturing layer technology, SLS/SLM involves the use of a high power laser (for example, a carbon dioxide laser) to fuse small particles of plastic, metal, ceramic or glass powders into a mass that has a desired three-dimensional shape.

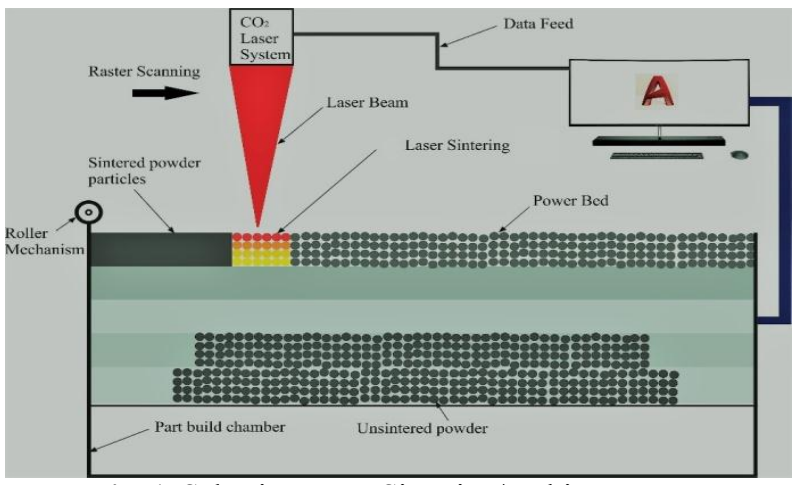

Fig. 1. Selective Laser Sintering/Melting process

Figure 1 provides the line sketch of Selective Laser Sintering/Melting process. Selective laser melting (SLM) is actually similar to SLS however, a high power laser is used as it requires more energy to sinter the metallic powder instead of base polymer powder as in the case of SLS. Thus the attributes of SLS/SLM process are:
I. Fastest additive manufacturing technique with potential to construct specimen of highly complex geometry that could not be constructed through any other approach.

II. Diverse structural and functional (including bio-compatible) characteristics are conceivable to fabricate materials in a diverse geometry. Concurrent attainment of multi-functional characteristics such as durability, conductivity and functionality is possible with this cuttingedge technology.

Thus SLS and SLM are laser based sintering processes, which are impacted by materials structure and geometry. These factors are in turn correlated to the amount of energy delivered to the surface of the powder. The laser power and scanning speed can significantly determine the final properties of the specimen and can have a substantial impact on the properties, like porosity and hardness of the end product layer [3]. The energy density of the laser beam per unit area is defined as [4]:

$$
E . D=P /(D \times v)
$$

Where;

E.D is the Energy Density $\left(\mathrm{J} / \mathrm{mm}^{-2}\right)$.

$P$ is the laser power (W).

$D$ the laser beam diameter $(\mathrm{mm})$.

$V$ is the laser scan velocity $(\mathrm{mm} / \mathrm{s})$.

Fuel cells and Electrolysers are those energy systems that are considered as "Game changers" of the next energy generation. The fuel for fuel cells, namely hydrogen can be derived from both renewable and nonrenewable sources by numerous processes $[5,6]$ and the fuel cell by itself in the reverse mode (electrolyser) can generate hydrogen through water. According to the U.S 
Department of Energy (DoE), "Hydrogen is a leading candidate because it can be clean, efficient and capable of production from diverse domestic resources, both renewable and non-renewable". Thus the fuel cell and electrolysers are potential candidates of electrochemical systems that can synergetically contribute to sustainability. Thus these energy systems can meet the growing energy demand of a nation and can apparently contribute to its GDP. Among the various fuel cells, PEM based one is widely used and has the potential to attract numerous niche markets due to its superior characteristics and power density compared to advanced batteries [7]. Also, their operating temperature is low with consequent rapid start up and dynamic response [8].

Similarly among the various electrolyser technologies PEM based electrolyser is the most simple and energy efficient technique to produce high quality hydrogen. Since, the reverse reaction of a fuel cell is the electrolysis the integrated fuel cell/electrolysis system can complement each other for the various load conditions. The infrastructure pertaining to storage and transportation of hydrogen are major challenges impeding the hydrogen economy and consequently PEM based electrolyser can serve as a substitute where hydrogen can be produced from water ON DEMAND. A regenerative PEM fuel cell is one such example which is capable of operating in both the fuel cell and electrolyser mode. While operating in fuel cell mode, it produces electricity from the hydrogen and oxygen/air. In the reverse mode, it acts as an electrolyser for generating hydrogen (which can be stored and used in fuel cell operational mode) and oxygen.

Extending the Selective Laser Sintering/Selective Laser Melting can significantly contribute to advanced PEM Fuel cells/Electrolyser component. The US department of energy (DoE) target can be easily realised through this AM technique. Thus the present paper provides a holistic review on various additive manufacturing techniques available in the literature that are incorporated to fabricate the key components involved in PEM fuel cell and Electrolyser system. It is a pre requisite to have an insight on various components involved in PEM fuel cells; so as to evaluate the compatibility of Additive manufacturing technique to fabricate them. The Section 2 provides a snapshot on the list of PEM Fuel Cell/Electrolyser components and their working principle. Section 2 also deals with the conventional manufacturing technique of the gas diffusion layer and bipolar plate components which are considered for the present assessment. Section 3 expounds on the additive manufacturing technique, namely the SLS and SLM process to fabricate the bipolar plate and gas diffusion layer components. Section 4 discusses the role of material selection in Additive Manufacturing and also provides critical recommendations. Section 5 emphases on the conclusion of the work.

\section{PEM Fuel Cell/Electrolyser Components}

PEM fuel cell/Electrolyser encompasses a pair of Gas Diffusion Electrodes (GDE), anodes and cathodes, and a Polymer Electrolyte Membrane (PEM) sandwiched between the electrodes. The gas diffusion electrode normally consists of a gas diffusion layer (GDL) and a catalyst layer (CL). Platinum or platinum alloys are principally used as an electro catalyst in most of the PEM fuel cell [9]/Electrolyser stacks due to its activity, selectivity and chemical stability [10]. Figure 2 illustrates that Pt. is the leading candidate to act as a catalyst [10].

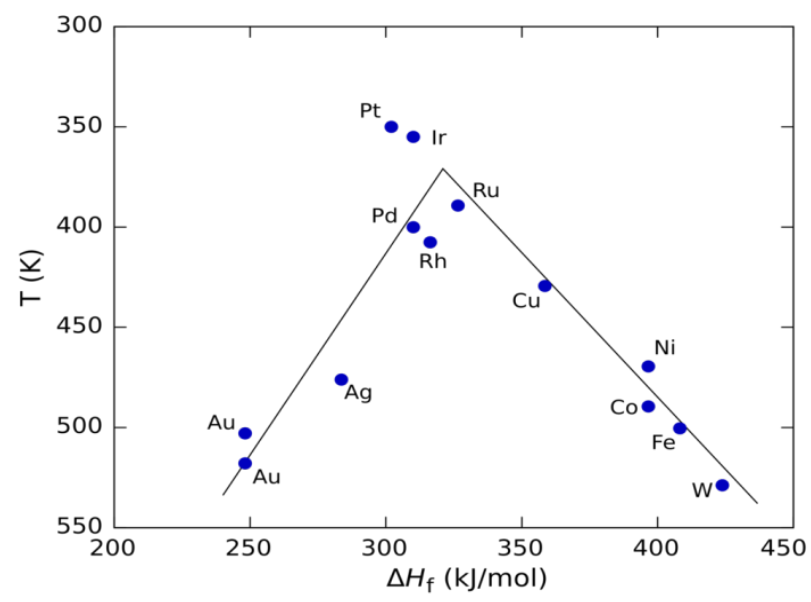

Fig. 2. Volcano plots screening the activity of Catalysts [10].

The gas diffusion electrodes are usually bonded to the membrane and the whole unit is entitled "Membrane Electrode Assembly (MEA)". Flow field plates are placed on both sides of MEA for supply of reactant gases to the electrodes. Table 1 provides a list PEM fuel cell/Electrolyser Components and also the feasibility of using AM technique to fabricate it.

Table 1 PEM fuel cell/Electrolyser Components

\begin{tabular}{|l|l|l|}
\hline Component & Function & $\begin{array}{l}\text { Additive } \\
\text { Manufacturing }\end{array}$ \\
\hline Membrane & $\begin{array}{l}\text { Transport the Protons } \\
\text { \& Impedes the flow of } \\
\text { Electrons. }\end{array}$ & No \\
\hline Catalyst Layer & $\begin{array}{l}\text { Aid Electrochemical } \\
\text { Reaction \& Must have } \\
\text { Optimal Mass Transport } \\
\text { Characteristics. }\end{array}$ & No \\
\hline $\begin{array}{l}\text { Gas Diffusion } \\
\text { Layer }\end{array}$ & $\begin{array}{l}\text { Facilitates diffusion of } \\
\text { reactant gases } \\
\text { Aids the transportation of } \\
\text { electricity, heat and } \\
\text { product water. } \\
\text { Prevents flooding in the } \\
\text { electrode }\end{array}$ & Yes \\
\hline $\begin{array}{l}\text { Flow field } \\
\text { plate } \\
\text { (Bipolar } \\
\text { plate). }\end{array}$ & $\begin{array}{l}\text { Transfer electrons } \\
\text { between adjacent cells. } \\
\text { Efficient thermal } \\
\text { management }\end{array}$ & Yes \\
\hline
\end{tabular}


The operation of the fuel cell involves the hydrogen (fuel) being supplied to the anode and oxygen/air being fed to the cathode; analogously in an electrolyser water is fed to the anode and the hydrogen is produced at cathode. Figure 2 illustrates the line sketch of PEM based fuel cell and electrolyser cell.
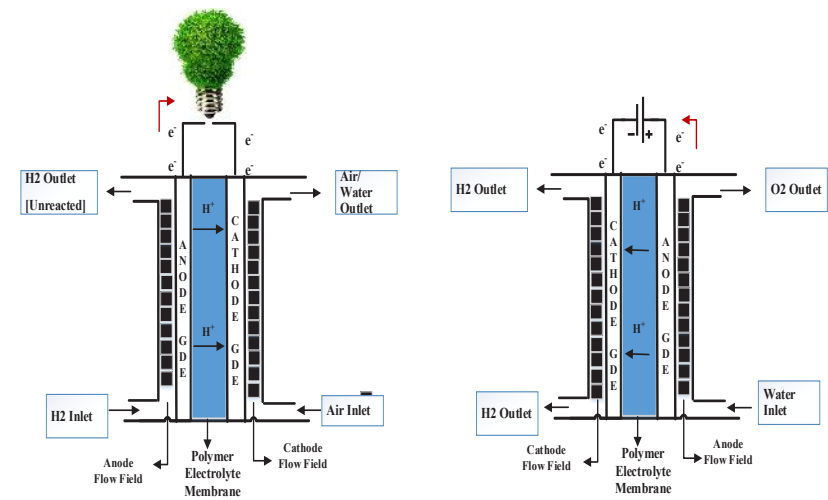

Fig. 3. A Plan of PEM fuel cell/electrolyser single cell, specifying integral components and Ion transfer [7].

As evident from Figure 3 and Table 1 the crucial components involved in the PEM fuel cell/electrolyser stack are a) Membrane b) Catalyst Layer c) Gas Diffusion Layer (GDL) and d) Flow field plate (Bipolar plate). Among these components gas diffusion layer and flow field plate (bipolar plate) are the two critical components. The incorporation of additive manufacturing technique can simplify the complexity and associated costs of production. As a consequence, the present paper critically assesses the list of AM techniques that are discussed in the literature to fabricate these two components.

\subsection{Gas Diffusion Layer and its Conventional Manufacturing Technique}

The GDL electrically interconnects the catalyst and current collector and thus acts as a pathway to the catalyst layer from the flow channels. It anatomically comprises of two layers, a hydrophobic agent (Poly Tetra Fluoro Ethylene) and a microporous layer made of Toray carbon paper or a carbon cloth that is covered with a microporous layer. Several GDL microscopic variables such as porosity, tortuosity, and permeability impact the behaviour of the fuel cells [11-14]. Figure 4 lists the two widely used conventional gas diffusion layer namely Carbon paper and Carbon cloth.

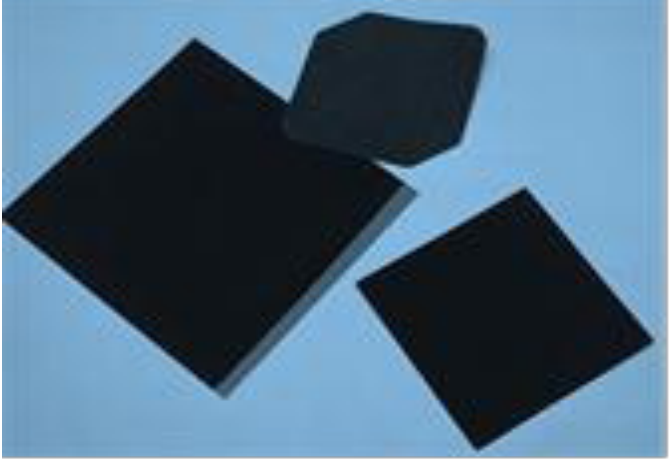

(a)

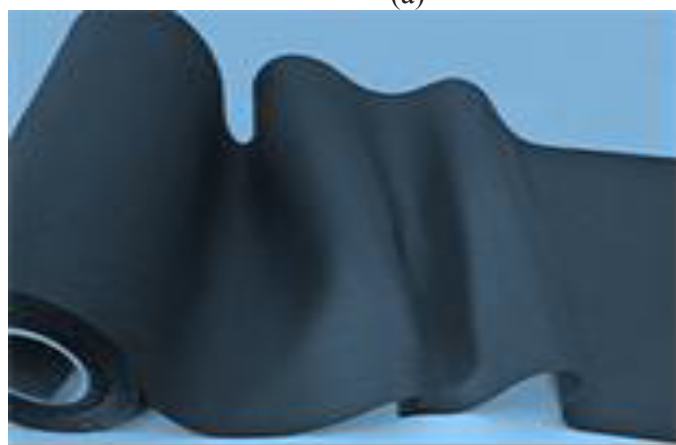

(b)

Fig. 4. Conventional gas diffusion layer a) Carbon paper b) Carbon cloth.

Though, there are numerous GDLs in the literature whose manufacturing techniques are parallel; the proposed paper considers SIGRACET ${ }^{\circledR}$ grade GDL 39 $\mathrm{BC}(325-\mu \mathrm{m}$ thickness) as a baseline material. The unique characteristics of SGL $39 \mathrm{BC}$ to consider is that it is denser and has a thicker microporous layer than its precursors (SGL $10 \mathrm{BC}$ ), and has a better water-retaining capability [15].

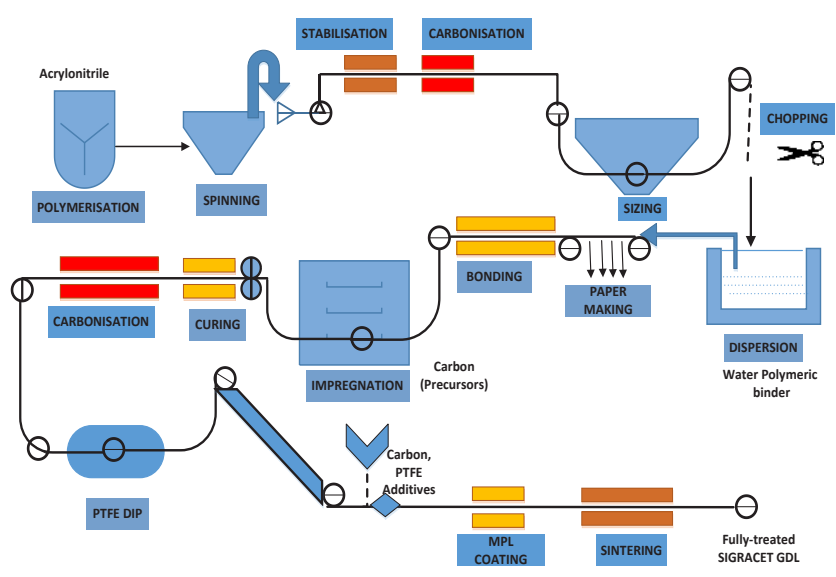

Fig. 5. Manufacturing steps involved in the conventional GDL-SGL 39 BC [15]

The manufacturing step is that of the well-known wet laying technology where the chopped carbon fibres are processed to a primary carbon fibre. The raw paper is then impregnated with carbonizable resins (carbonizable resins with the optional addition of carbon fillers), cured and recarbonized/graphitized [15]. 


\subsection{Bipolar plate and its Conventional Manufacturing Technique}

The flow field or bipolar plate are conductive plates that are typically made of graphite. They account for $40-50 \%$ of the cost and $60-80 \%$ of the weight of a PEM fuel cell stack $[16,17]$. They act as a structural and electrical spine for linking the cells in series [18]. Figure 6 portrays the processes for making compression-moulded and injection-moulded bipolar plates.

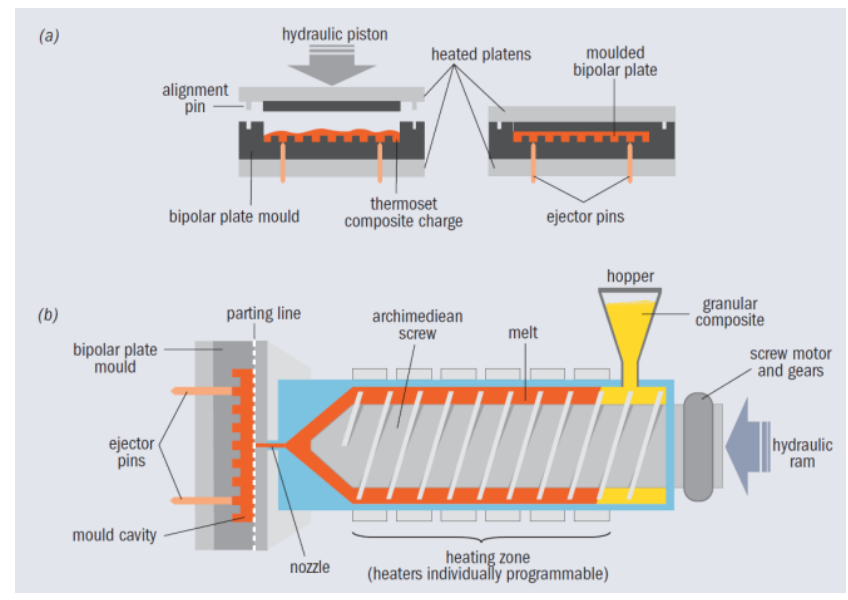

Fig. 6. Conventional Manufacturing of Bipolar Plate (a) Compression-moulded (b) Injection-moulded [19]

A variety of bipolar plate designs are known, and the conventional designs typically comprise either pin, integrated cooling flow fields, interdigitated flow field, parallel or serpentine designs [20]. The time required for designing/manufacturing bipolar plates (BPP) with complex flow channels is a challenge for PEM electrolyser [21] and PEM fuel cell fabrication. It is evident from Figure 6 (b) that the conventional manufacturing technique of bipolar plate is a lengthy process similar to the conventional GDL manufacturing process.

\section{AM techniques to fabricate GDL and Bipolar Plate}

\subsection{GDL Manufacture by Selective Laser Sintering}

Convention Carbon based GDL is prone to the electrochemical degradation which is due to the oxidation of carbon (present in the carbon paper) to carbon dioxide and is illustrated in equation:

$$
\begin{aligned}
& \mathrm{C}+2 \mathrm{H}_{2} \mathrm{O} \rightarrow \mathrm{CO}_{2}+4 \mathrm{H}^{+}+4 e^{-} \\
& E_{o}=0.207 \mathrm{~V} v \mathrm{~s} . \mathrm{SHE}
\end{aligned}
$$

In addition, the manufacturing step involved is complex which is evident from Figure 4. So SLS process can apparently improve the durability of GDL as they are susceptible to electrochemical oxidation $[22,23]$ as well as reducing the manufacturing complexity because the SLS process is:

I. Fastest additive manufacturing technique where complex geometry structure could be easily constructed.

II. Diverse structural and functional possibilities are possible.

In the previous investigation, we incorporated alumide [24] as the base material since it is stiffer than many other materials used in $3 \mathrm{D}$ printing and it contributes to good flexural strength and higher thermal load [25]. Though the mechanical and electrical characteristics of alumide are compatible for PEM operating conditions, one of the severe limitations from the fundamental chemistry perspective is that the aluminium present in the alumide is prone to oxidation in the PEM fuel cell environment resulting in the metal ions formed which could potentially damage the expensive membrane component. Other researchers [17] [26, 27] reported that aluminium exposed to a PEM fuel cell operating environment are prone to such a corrosion. As a consequence, polyamide is used as the base material to develop the thin film samples. The utilization of titanium structures has already been proposed by Hottinen et al. [28] and it is a safe material for GDL application. In the unique investigation conducted by us [29], the base powder (PA) is sintered in a precise mode; appropriate functional material (Ti) is added to the base powder to attain the desirable electrical and thermal characteristics.

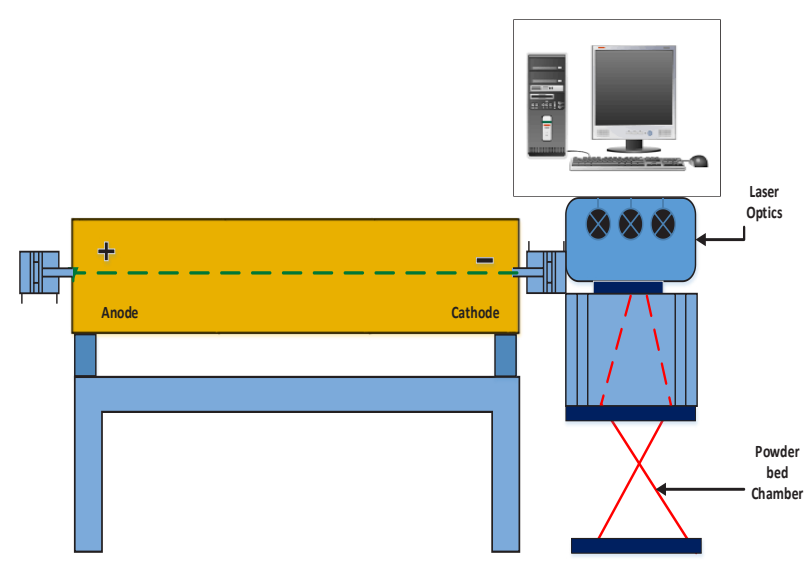

Fig. 7. Line sketch of SLS experiment set-up [30]

Figure 7 illustrates the experiment set-up of the SLS process. The initial temperature of the powder bed was kept at around $70^{\circ} \mathrm{C}$ to keep the powder substrate dry and free of moisture. To study the diffusion and bonding of the Titanium (Ti) powder the experiments are 
executed by varying the power as illustrated in Table 3 for a fixed scanning speed of $450 \mathrm{~mm} / \mathrm{s}$.

Table 2. Laser power required to sinter various configuration of Polyamide/Titanium

\begin{tabular}{|l|l|}
\hline Laser Power (W) & $\begin{array}{l}\text { Polyamide/Titanium } \\
\text { Composition (\%) }\end{array}$ \\
\hline 15 & $90 / 10$ \\
\hline 12 & $80 / 20$ \\
\hline 9 & $70 / 30$ \\
\hline
\end{tabular}

It may be noted that with increasing Ti content, the laser power required is decreased in order to achieve a continuous sintered layer. This is due to the fact that the titanium component absorbs the heat from the laser and burns partly, which is an exothermic reaction, resulting in excessive thermal energies. Consequently, the higher the titanium content, the lower the energy density level for laser sintering.

\subsection{Bipolar Plate Manufacture by Selective Laser Melting}

Metals, as sheets, are potential candidates for bipolar plate material since they have good mechanical stability, electrical and thermal conductivity and gas impermeability [17]. Probably the most important benefit is that the resultant fuel cell/electrolyser stack can be more compact and lighter than graphite BPP plates. The utilization of additive manufacturing technique is very much compatible for the bipolar plate fabrication because various design configurations are easily accomplished with this approach [31]. It is well evident that laser power is the significant contributor to the material characteristics and it is evident from the literature [31] that the electrical conductivity increases significantly $(>220 \mathrm{~S} / \mathrm{cm})$ with a corresponding increase in pyrolyzing temperature.

Yang et al [32] incorporated selective laser melting (SLM) techniques which is actually a subset of selective laser sintering (SLS) technique to fabricate a stainless steel (SS) plate with parallel flow field that can serve as an integrated cathode bipolar plate and a current distributor. Their results demonstrated that the PEM based electrolyser with the integrated bipolar plate can achieve an excellent performance for hydrogen production for a voltage of $1.779 \mathrm{~V}$ and a current density of $2.0 \mathrm{~A} / \mathrm{cm}^{2}$. Thus, with the $\mathrm{AM}$ technique the components involved in the PEM fuel cell stack can be integrated. Yang et al [33] also directly printed an integrated bipolar plate which functions as a liquid/gas diffusion layer, bipolar plate, gasket, and current distributor. The interfacial contact resistances between the parts were eliminated, and the size is made more compact providing an excellent energy efficiency of up to $86.48 \%$

Ssuwei Chen et al [34] used a selective laser sintering (SLS) technique to fabricate a graphite based bipolar plate. Their observation is that the relative particle size and composition of the constituents plays an imperative role in the product design. Unlike, titanium or stainless steel extreme care must be taken, mainly because of the intrinsic brittleness of graphite and thin part dimensions. Thus SLS can be a costly and time- consuming machining process with graphite material.

Though stainless steel, titanium and graphite have been used for AM fabrication; the key focus is on titanium BPPs, rather than the steels or graphite. The high strength-to-weight ratio of Ti-alloy also makes it an ideal material for applications where power-to-weight is paramount and also previously it has been demonstrated to fabricate a single-cell fuel cell by the application of direct metal laser sintering [35]. As a consequence titanium can perform robustly in a fuel cell operating environment and subsequently it is used as a bipolar plate in the Toyota Mirai Fuel cell Electric Vehicle [18, 36]. Figure 8 illustrates the photograph of a Toyota Mirai Fuel cell Vehicle and the PEM Fuel cell stack incorporated in it.

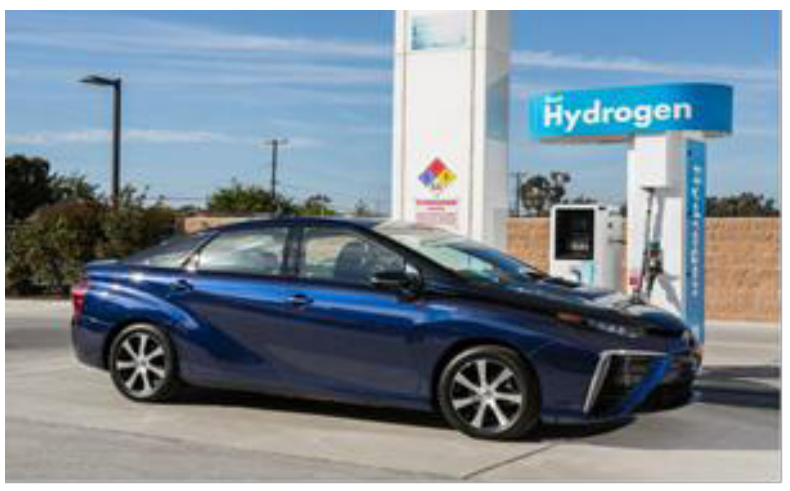

(a)

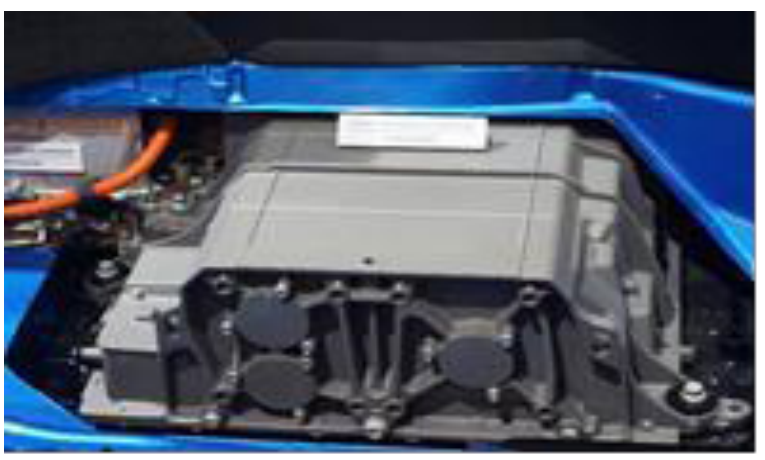

(b)

Fig. 8. Toyota Mirai a. Fuel cell Vehicle b. Fuel cell stack 
Additive manufacturing has been used for the creation of composite parts in general and bipolar plates specifically $[37,38]$. Direct metal laser sintering has also been previously demonstrated for the fabrication of one-piece BPPs for a single-cell and 40-cell fuel cell stack and the performances are evaluated [39]. It is inferred that the single-cell comprising 2 BPPs is similar to that of an analytical cell made from carbon.

\section{Discussion and Recommendation}

Additive manufacturing (AM) technology, also called rapid prototyping or 3D printing, allows high resolution material to be printed from three-dimensional (3D) digital models instead of cutting materials from an initial bulk. It has found its application in diverse field of engineering and recently extended to the fuel cell/electrolyser manufacturing.

Appropriate material selection is an essential criteria to infuse, appropriate strength, electrical and thermal conductivity. However, they must be selected based on the corrosion resistance and its compatibility with PEM fuel cell working environment. Table 3 provides a consequence, a short assessment of the corrosion rate of various metals [40] which can provide an insight to choose the material for both the gas diffusion layer and bipolar plate manufacturing.

Table 3. Corrosion rates of materials [40]

\begin{tabular}{|l|l|}
\hline Material & $\begin{array}{l}\text { Corrosion rate } \\
(\boldsymbol{\mu m} \text { per year })\end{array}$ \\
\hline Aluminum & $\sim 250$ \\
\hline Copper & $>500$ \\
\hline Gold & $<15$ \\
\hline Graphite & $<15$ \\
\hline Nickel & $>1000$ \\
\hline Silver & $<15$ \\
\hline Tin & $>10000$ \\
\hline Titanium & $<100$ \\
\hline Tungsten & $<100$ \\
\hline Zinc & $>2000$ \\
\hline Gold-nickel & $\sim 500$ \\
\hline Phosphorous-nickel & $<30$ \\
\hline SS 316L & $<100$ \\
\hline
\end{tabular}

However, it is eminent that these metallic material properties alone cannot be considered as a standard due to the diverse operating conditions in PEM fuel cell operating environments such as low $\mathrm{pH}$, high power/high voltage, and high-temperature operation. This operating condition while happening concurrently can potentially damage even low corrosive material like graphite (graphite is a carbon allotrope and can be oxidised to
$\mathrm{CO}_{2}$ ) specifically at a voltage greater than $0.207 \mathrm{~V}$ [22]. Ironically, titanium is a potential material to resist corrosion even at highly acidic and humid conditions consequently, complementing its usage for PEM fuel cell environment.

The stainless steel material is corrosion and acid resistant steel alloy used for medical implants. Its excellent corrosion resistance combined with its high hardness and toughness permits the experimenter to re-use the micro fuel cell fabricated from it, many times [41]. Alternatively, 3D-printing could also be integrated with traditional milling processes to $3 \mathrm{D}$-print the hollow features of the BPP, followed by milling of the high tolerance mating features [39]

\section{Conclusion}

Additive Manufacturing is a promising technology that has the potential to achieve high efficient, reliable and robust material configuration in a cost effective manner. Functional characteristics such as controlled pore morphology, electrical and thermal conductivity, tensile characteristics, hydrophobicity, etc which are the critical requirements for the PEM fuel cell/electrolyser are feasible with the AM technique. Streamlining the design alignment and integrating the key PEM Fuel cell/Electrolyser components are critical factors that can circumvent its limitations and possibly lead to its commercialisation.

\section{References}

1. C.R. Deckard, Method and apparatus for producing parts by selective sintering. 1989, Google Patents.

2. N. Guo and M.C. Leu, Frontiers of Mechanical Engineering, 2013. 8(3): p. 215-243.

3. N.B. Dahotre, and S. Harimkar, Laser fabrication and machining of materials. 2008: Springer Science \& Business Media.

4. J.C. Nelson, 1993, University of Texas at Austin.

5. M. Ay, A. Midilli, and I. Dincer, International journal of energy research, 2006. 30(5): p. 307321.

6. G. Sasikumar, A. Muthumeenal, S. SundarPethaiah, N. Nachiappan, R. Balaji, International Journal of hydrogen energy, 2008. 33(21): p. 5905-5910.

7. A. Jayakumar, S. Pethaiah Sethu, M. Ramos, J. Robertson, A. Al-Jumaily, Ionics, 2015. 21(1): p. 1-18.

8. J.A. Kumar, P. Kalyani, and R. Saravanan, Int. J. Electrochem. Sci., 3 (2008) 961 - 969.

9. S.S. Pethaiah, et al., Ionics, 2011. 17(4): p. 361366.

10. O.T. Holton, and J.W. Stevenson, Platinum Metals Review, 2013. 57(4): p. 259-271. 
11. M. Espinoza, M. Andersson, J. Yuan, B. Sundén, International Journal of Energy Research, 2015. 39(11): p. 1528-1536.

12. S. Park, J.W. Lee, and B.N. Popov, International Journal of Hydrogen Energy, 2012. 37(7): p. 5850-5865.

13. M. Mathias, et al., Diffusion media materials and characterisation. Handbook of fuel cells, 2003.

14. D. Gerteisen, T. Heilmann, and C. Ziegler, Journal of Power Sources, 2008. 177(2): p. 348354.

15. R. Schweiss, C. Meiser, T. Damjanovic, I. Galbiati, N. Haak, SIGRACET® Gas Diffusion Layers for PEM Fuel Cells, Electrolyzers and Batteries. 2016.

16. H. Tsuchiya and O. Kobayashi, International Journal of Hydrogen Energy, 2004. 29(10): p. 985-990.

17. A. Hermann, T. Chaudhuri, and P. Spagnol, International journal of hydrogen Energy, 2005. 30(12): p. 1297-1302.

18. K.S. Lyons, and B.D. Gould. Fuel Cells. in Materials Science Forum. 2017. Trans Tech Publ.

19. D. Brett and N. Brandon, Fuel Cell Review, 2005. 2(1): p. 15-23.

20. X. Li and I. Sabir, International journal of hydrogen energy, 2005. 30(4): p. 359-371.

21. I.U. Hwang, H.N. Yu, S.S. Kim, D.G. Lee, J.D. Suh, S.H. Lee, B.K. Ahn, S.H. Kim, T.W. Lim, Journal of Power Sources, 2008. 184(1): p. 9094.

22. J. Wu, X.Z. Yuan, J.J. Martin, H. Wang, J. Zhang, J. Shen, S. Wu, W. Merida, Journal of Power Sources, 2008. 184(1): p. 104-119.

23. D. Stevens and J. Dahn, Carbon, 2005. 43(1): p. 179-188.

24. A. Jayakumar, M. Ramos, and A. Al-Jumaily. International Mechanical Engineering Congress and Exposition. 2016. American Society of Mechanical Engineers.

25. H. Ju, H. Meng, and C.-Y. Wang, International Journal of Heat and Mass Transfer, 2005. 48(7): p. 1303-1315.

26. Y. Hung, K. El-Khatib, and H. Tawfik, Journal of Power Sources, 2006. 163(1): p. 509-513.

27. A.S. Woodman, E.B. Anderson, K.D. Jayne, and M.C. Kimble, 1999. AMERICAN ELECTROPLATERS AND SURFACE FINISHERS SOCIETY INC.

28. T. Hottinen, M. Mikkola, T. Mennola, P. Lund Journal of power sources, 2003. 118(1): p. 183188.

29. A. Jayakumar, S. Singamneni, M. Ramos, A.M Al-Jumaily, S.S. Pethaiah, Materials, 2017. 10(7): p. 796.

30. R. Velu and S. Singamneni, Evaluation of the influences of process parameters while selective laser sintering PMMA powders. Proceedings of the Institution of Mechanical Engineers, Part C:
Journal of Mechanical Engineering Science, 2015. 229(4): p. 603-613.

31. K. Alayavalli and D.L. Bourell, Rapid prototyping journal, 2010. 16(4): p. 268-274.

32. G. Yang, J. Mo, Z. Kang, F.A. List, J.B. Green, S.S. Babu, F.Y. Zhang, International Journal of Hydrogen Energy, 2017. 42(21): p. 1473414740.

33. G. Yang, J. Mo, Z. Kang, Y. Dohrmann, F.A. List, J.B. Green, S.S. Babu, F.Y. Zhang, Applied Energy, 2018. 215: p. 202-210.

34. S. Chen, J. Murphy, J. Herlehy, D.L. Bourell, K. L. Wood, Rapid Prototyping Journal, 2006. 12(5): p. 275-282.

35. C.J. Netwall, B.D. Gould, J.A Rodgers, N.J Nasello, K.E. Swider-Lyons, Journal of Power Sources, 2013. 227: p. 137-144.

36. K. Kojima and K. Fukazawa, ECS Transactions, 2015. 69(17): p. 213-219.

37. S. Chen, D.L. Bourell, and K.L. Wood. International SFF Symposium, Austin, TX, August. 2004.

38. B. Lyons, M. Batalov, P. Mohanty, S. Das, SFF Symposium, Austin, TX. 2005.

39. B.D. Gould, J.A. Rodgers, M. Schuette, K. Bethune, S. Louisa, R. Rocheleau and K. Swider-Lyons, ECS Journal of Solid State Science and Technology, 2015. 4(4): p. P3063P3068.

40. Lee, S.-J., C.-H. Huang, and Y.-P. Chen, Journal of materials processing technology, 2003. 140(1): p. 688-693.

41. G. Scotti, et al., P. Kanninen, T. Kallioand S. Franssila, Journal of Micromechanics and Microengineering, 2012. 22(9): p. 094006. 